\title{
低消費電力化を目的とした電動アシスト車いすの ファジィ推論型走行効率向上制御
}

\section{Fuzzy Inference Type Driving Efficiency Improvement Control of}

\section{Power-Assisted Wheelchair for Low Power Consumption}

\author{
○学 深田 翔 (千葉工大) 非 小笠 義幸（千葉工大） \\ 非 村上 博紀（吉野工業所） 正 関 弘和（千葉工大）
}

Sho FUKADA, Chiba Institute of Technology, s0822284BA@it-chiba.ac.jp
Yoshiyuki OGASA, Chiba Institute of Technology
Hiroki MURAKAMI, Yoshinokogyosho Corporation
Hirokazu SEKI, Chiba Institute of Technology, seki.hirokazu@it-chiba.ac.jp

This paper describes a fuzzy driving control scheme of power-assisted wheelchairs for the low power consumption. The proposed fuzzy system suppresses the maximal assisted torque and keeps the low torque for inertial driving based on the human input torque and driving velocity information. Long distance driving experiments comparing with the manufactured wheelchair shows the effectiveness of the proposed control system.

Key Words: Power-assisted wheelchair, Driving control, Low power consumption, Fuzzy inference, Driving efficiency

\section{1. 緒言}

本稿では電動アシスト車いすの多機能・高性能走行制御の 一つとして，同じ距離を走行するのにより低消費電力となる ような新しいアシストトルク生成法を提案し実験的検討を行 うものである。

電動アシスト車いすは，搭乗者の入力した力に対し電気モ ータにより補助し，その増幅された力で駆動するものである。 筋力の落ちた高齢者，障害者でも利用でき，行動範囲を広げ るものとして期待は大きい。ヤマハ製 JW-II[1]が有名であるが, 実際の走行場面においては, 段差の踏破, 坂道や不整地での 走行, 操作性向上など様々な問題点も存在する。多機能化 ・ 高性能化の研究例として回生ブレーキ制御[2]や高外乱路面走 行制御[3]なども行われている。

電動車いすはバッテリが唯一のエネルギー源であり，もし 外出中にバッテリが切れると使用者にとって大きな負担とな るため，例えば同じ距離を走行するのにも，乗り心地なども 考慮しながら，できるだけ消費電力を抑えることが重要とな る。そこで本研究では，走行距離あたりの消費電力がより低 くなるようなアシストトルク生成をファジィ推論によって行 う新しい走行制御法を提案し，実験用車い寸と製品版車いす を用い検証を行う。

\section{2. 電動アシスト車いすの制御}

電動アシスト車いすのシンプルな走行制御法の一つとして, 筆者らによって提案されている一次遅れ系によるアシスト走 行制御法がある。この制御システムの構成図を図 1 に示す。 トルクセンサから得た人間の入力トルク $T_{h}$ に対して一次遅れ 系を介し，その時定数 $\tau_{a}$ を切り替えている。 $T_{a}$ はアシスト卜 ルク出力, $T_{d}$ は外乱トルク, $\alpha$ はアシスト比であり, $T_{a}$ は式(1) のように表現できる。車輪の回転角度 $\theta$, あるいは移動距離 $x$ が制御系の出力となる。時定数 $\tau_{a}$ の設計については, 操作者 がハンドリムを握り入力トルクを増加させている間は時定数 を小さくして（ $\tau_{a}=\tau_{f}$, これを立ち上がり時定数と呼ぶことと する）アシストトルクの速い立ち上がりを実現し，手を放し 入力トルクが減少して以降は時定数を大きくして $\left(\tau_{a}=\tau_{s}\right.$, こ れを惰性時定数と呼ぶこととする）惰性走行を生み出す。こ のようなアシスト制御法を左右輪それぞれに適用しアシスト
車いすの走行が実現される。なお左右輪で区別するため各変 数の右上に $r, l$ の添え字を加える。

$$
T_{a}=\frac{\alpha}{1+\tau_{a} s} T_{h}
$$

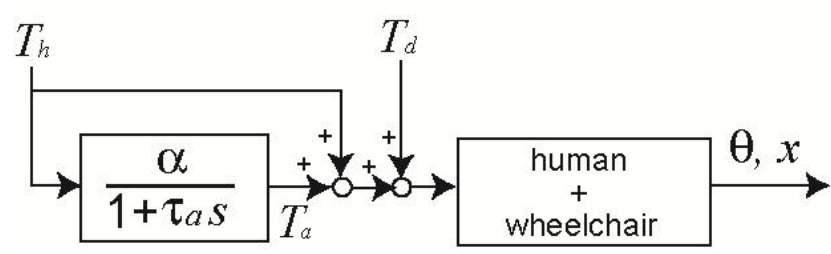

Fig. 1 Assist control system with LPF

本研究ではこの手法を従来手法（LPF モード）とし，次章 の走行効率検証や提案手法との比較検証に用いる。なおアシ スト比と時定数は $\alpha=1.2, \tau_{s}=0.5[\mathrm{~s}], \tau_{f}=0.05[\mathrm{~s}]$ とするが，こ れは製品版の車い寸に近い走行となるよう設定している。

\section{1 走行効率の定義}

\section{3. 走行パターンと走行効率の検証}

本研究では同じ距離を走るのにできるだけ消費電力を抑制 した走行を実現することを目指す。そのために，これを定量 的に評価する指標を定義する。

まず消費電力 $P[\mathrm{~W}]$ にいて今回は車輪に搭載されている直 流モー夕における銅損のみに着目し, 巻線抵抗 $R[\Omega]$ と左右輪 のモータ電流 $I_{l}, I_{r}[\mathrm{~A}]$ を用いて計算し, これを時間積分したも のを消費電力量 $Q[\mathrm{~W} ・ \mathrm{~s}]$ とする。モータ電流は電流センサに より計測する。

$$
Q=\int\left(R I_{r}^{2}+R I_{l}^{2}\right) d t
$$

また自動車における燃費と同様の考えにより, 消費電力量 $Q$ に対する走行距離 $d[\mathrm{~m}]$ の割合を「走行効率」 $D[\mathrm{~m} / \mathrm{W} \cdot \mathrm{s}]$ と定 義する。

$$
D=\frac{d}{Q}
$$




\section{2 アシストトルクパターンによる走行効率検証}

モータ電流を抑えることが消費電力抑制につながるが，モ 一タ電流はアシストトルク指令と比例関係にあるため，アシ ストトルクを様々に調整することで消費電力低下の実現が期 待できる。ここでは前章で述べた従来手法を用い, 各パラメ 一夕を様々に変化させることで消費電力低下の可能性を探る。

今回はアシスト比と惰性時定数を変化させることにより, どのようなアシストトルク生成が低消費電力を実現するかを 検証する。惰性時定数については図 2 のようにアシストトル クのピーク值を $100 \%$ とした際にこれを 4 分割した時間帯それ ぞれで值を設定し，詳細な変化まで検証する。

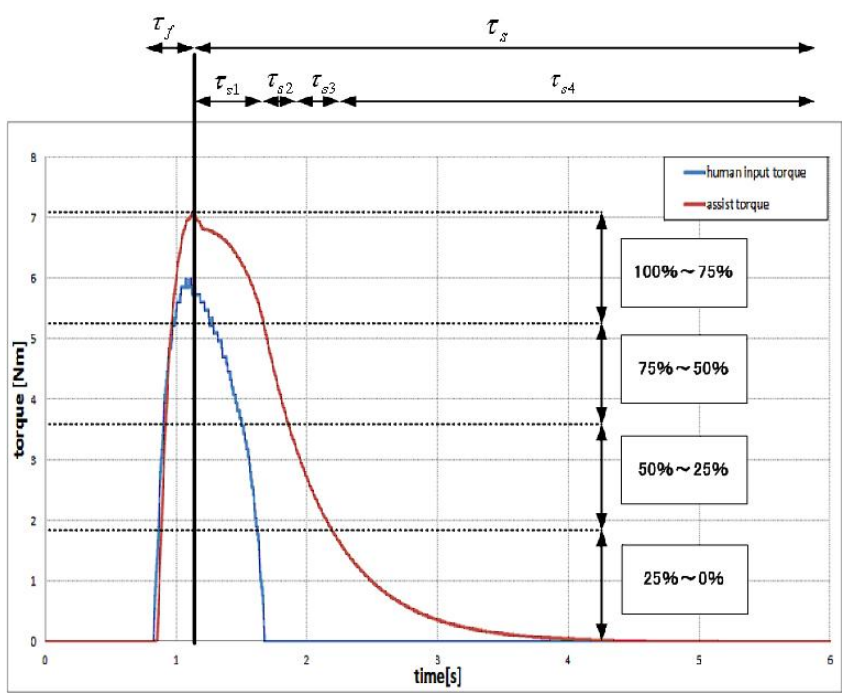

Fig. 2 Control parameters

アシスト比 $\alpha$, 惰性時定数 $\tau_{s 1}, \tau_{s 2}, \tau_{s 3}, \tau_{s 4}$ を様々に変化さ せ検証を行った結果，アシストトルクは「できるだけ最大值 を抑え，その後速やかに減少させ，低い值で㤢性を維持する」 とした場合に走行効率が向上する傾向が見られた。

この考えに基づき，一漕ぎでの走行距離を $1.5[\mathrm{~m}], 2.5[\mathrm{~m}]$, $3.5[\mathrm{~m}], 4.5[\mathrm{~m}]$ と設定し, それぞれの距離を実現するような $\alpha$, $\tau_{s 1}, \tau_{s 2}, \tau_{s 3}, \tau_{s 4}$ の組み合わせを作成し走行実験を行った。こ れらの走行効率の結果を図 3 に示す。いずれの距離において もアシスト比を小さくしてトルクの最大值を抑制し惰性を伸 ばし走行距離を得ることで走行効率が向上できることがわか る。

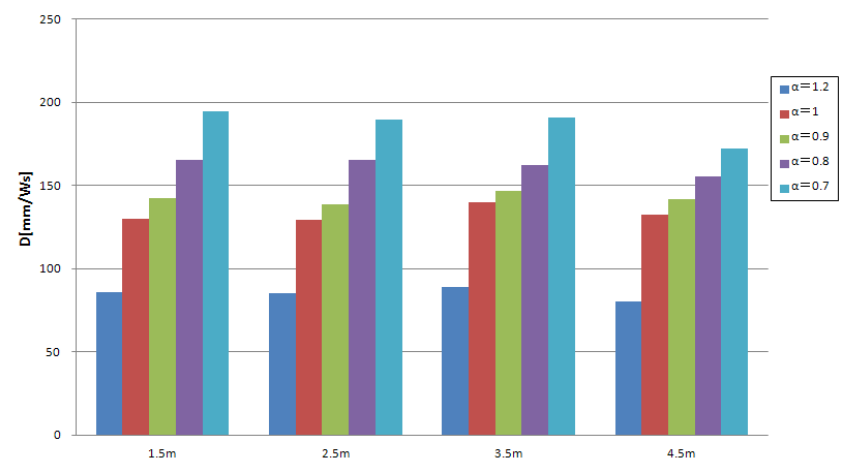

Fig. 3 Driving efficiency validation

アシスト比と時定数の調整で低消費電力の実現もある程度 可能であるが，いくつかの問題点も浮かんだ。例えば，アシ スト比を低くするとトルクの最大值は低下するが，加速の程
度も遅くなり操作者にとってハンドリムを漕ぐ負担が増加し てしまう。また，すでに速度が出ている二漕ぎ目以降のトル ク生成にも柔軟に対応しなければならないが，これらのパラ メータだけではトルク調整に限界があると言える。

\section{4. ファジィ推論に基づく低消費電力走行制御法}

\section{1 提案手法の概要}

本研究では，操作者がハンドリムを漕ぐ動作をしている前 半と, 手を離して惰性走行を行う後半のそれぞれに対し，フ アジィ推論を適用し，低消費電力を実現するアシストトルク を生成する手法を提案する。提案する制御手法の全体構成を 図 4 に示す。

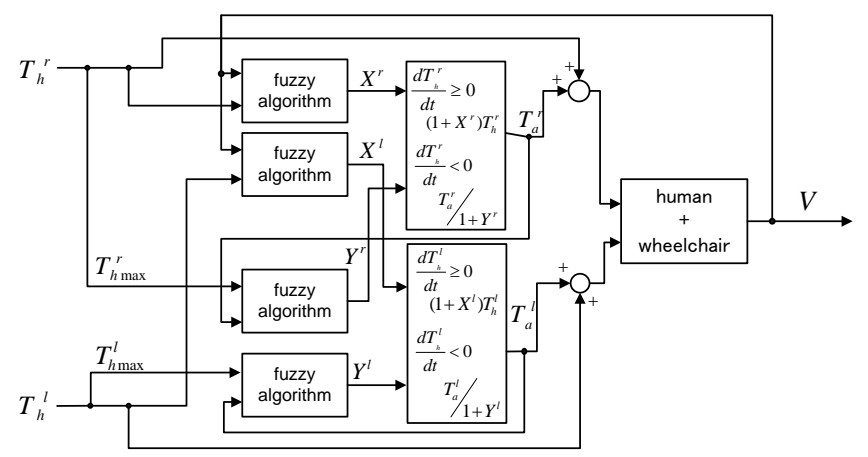

Fig. 4 Block diagram of proposed control system

ハンドリムを漕いでいる前半は，入力トルクの傾き（微分 值）が正であることで判断し，負であれば手を離した後半と 判断する。前半は式(4)に従い, パラメータ $X\left(X^{r}, X^{l}\right)$ を推論 することで立ち上がりのアシストトルクを生成する。後半は 式(5)に従い，パラメータ $Y\left(Y^{r}, Y^{l}\right)$ を推論することで惰性の ためのトルクを生成する。 $k$ 制御周期目のアシストトルク指令 值は以下のように表現される。

$$
\begin{gathered}
T_{a}^{r, l}[k]=\left(1+X^{r, l}\right) T_{h}^{r, l}[k] \\
T_{a}^{r, l}[k]=\frac{T_{a}^{r, l}[k-1]}{1+Y^{r, l}}
\end{gathered}
$$

\section{2 ファジィ推論の設計}

まず前半の立ち上がりのトルク生成については，操作者の 入力トルク $T_{h}{ }^{r}, T_{h}{ }^{l}$, 走行速度 $V$ の二つの情報を用い, 加速時 のアシストトルクを決めるパラメータ $X$ を推論する。これら はいずれも三角型メンバシップ関数によりファジィ変数設計 を行い, それぞれ SS(Small-Small), S(Small), M(Middle), B(Big), $\mathrm{BB}(\mathrm{Big}-\mathrm{Big})$ )各グレード值を求める。これらを基に, 図 5 の ルールに従って推論する。図 6 は推論出力のシングルトン型 ファジィ変数である。入力トルクが小さい, つまり漕ぎ始め のときにはアシストトルクの立ち上がりを大きくし，その後 に徐々に弱めていく。また速度情報も用い, 寸でに速度が出 ている二漕ぎ目以降にはあまりアシストトルクが大きくなら ないようにルールを設計している。 


\begin{tabular}{|c|c|c|c|c|c|}
\hline$V T_{h}^{r, l}$ & SS & S & M & B & BB \\
\hline SS & BB & BB & B & M & S \\
\hline S & BB & B & M & M & S \\
\hline M & BB & B & M & S & SS \\
\hline B & B & M & M & SS & SS \\
\hline BB & B & M & S & SS & SS \\
\hline
\end{tabular}

Fig. 5 Fuzzy rules for control parameters for parameter $X$

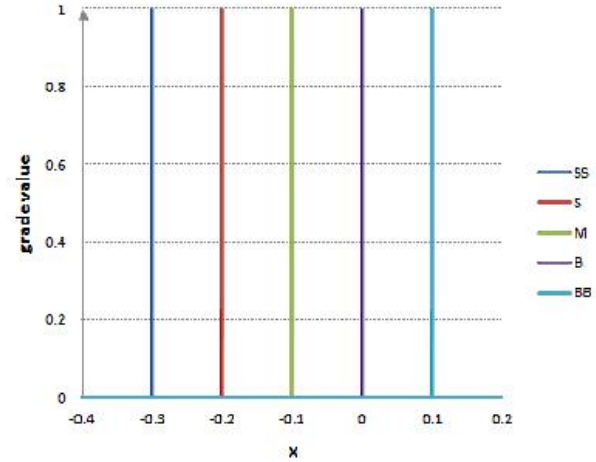

Fig. 6 Singleton-type fuzzy reasoning for parameter $X$

次に後半の惰性トルク生成については，入力トルクの最大 值 $T_{h \max }{ }^{r}, T_{h \text { max }}{ }^{l}$, アシストトルク $T_{a}^{r}, T_{a}^{l}$ の二つの情報を用い, 現在のアシストトルクを減少させる割合を決めるパラメータ $Y$ を推論する。これらも先ほどと同様に三角型メンバシップ関 数により SS, S， M, B， BB の各グレード值を求める。これ らを基に, 図 7 のルールに従って推論する。図 8 は推論出力 のシングルトン型ファジィ変数である。現在のアシストトル クが大きいほじ減少率を大きくし，アシストトルクを下げ, また入力トルクの最大值によってもこれらを変化させている。

\begin{tabular}{|c|c|c|c|c|c|}
\hline$T_{h \max }^{T_{a}^{r, i}}$ & $\mathrm{SS}$ & $\mathrm{S}$ & $\mathrm{M}$ & $\mathrm{B}$ & $\mathrm{BB}$ \\
\hline $\mathrm{SS}$ & $\mathrm{M}$ & $\mathrm{B}$ & $\mathrm{BB}$ & $\mathrm{BB}$ & $\mathrm{BB}$ \\
\hline $\mathrm{S}$ & $\mathrm{S}$ & $\mathrm{M}$ & $\mathrm{BB}$ & $\mathrm{BB}$ & $\mathrm{BB}$ \\
\hline $\mathrm{M}$ & $\mathrm{S}$ & $\mathrm{S}$ & $\mathrm{M}$ & $\mathrm{BB}$ & $\mathrm{BB}$ \\
\hline $\mathrm{B}$ & $\mathrm{SS}$ & $\mathrm{SS}$ & $\mathrm{S}$ & $\mathrm{BB}$ & $\mathrm{BB}$ \\
\hline $\mathrm{BB}$ & $\mathrm{SS}$ & $\mathrm{SS}$ & $\mathrm{SS}$ & $\mathrm{B}$ & $\mathrm{B}$ \\
\hline
\end{tabular}

Fig. 7 Fuzzy rules for control parameters for parameter $Y$

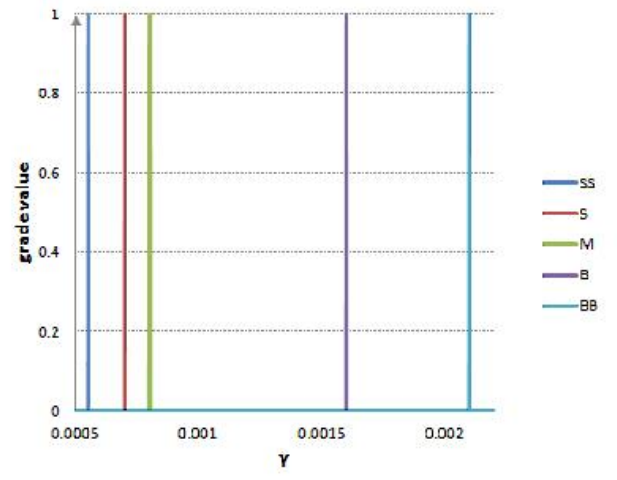

Fig. 8 Singleton-type fuzzy reasoning for parameter $Y$

\section{1 実験装置の概要}

\section{5. 実験による検証}

本提案手法の有効性を示すために実験による検証を行う。 ヤマ八発動機 (株) 製の電動アシスト車いす JW-II をべースに 製作した実験装置の外観を図 9 に示す。電流センサによるモ 一夕電流測定や車輪角度の計測, 全体の制御などは ART-Linux を導入した PCにより行う。制御周期は $1[\mathrm{~ms}]$ である。
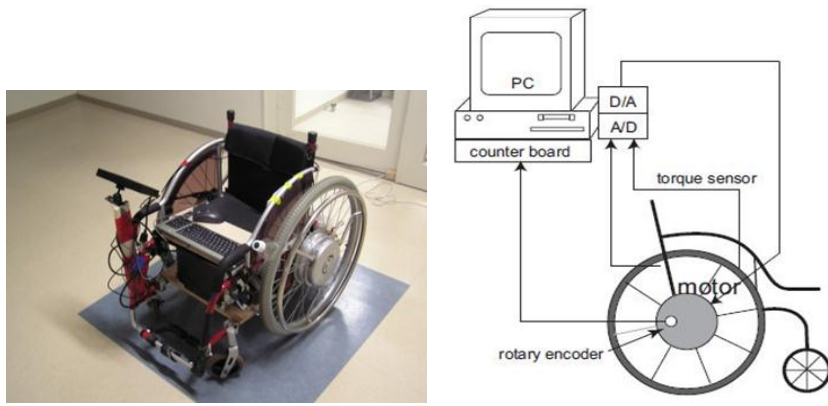

Fig. 9 Experimental setup

\section{2 基礎的検証実験}

本提案手法の有効性を示すため最初に，一漕ぎから三漕ぎ 程度の短距離走行実験により従来手法と提案手法の比較検証 を行う。屋内の平坦な廊下において, 一漕ぎで $1.5[\mathrm{~m}], 2.5[\mathrm{~m}]$, $3.5[\mathrm{~m}], 4.5[\mathrm{~m}]$ 走行する実験, 三漕ぎで $8.5[\mathrm{~m}]$ 走行する実験を 行うが，両手法に対し同じ力で漕ぐように統一する.

これらの実験の一例として, 三漕ぎで $8.5[\mathrm{~m}]$ を走行する実 験について, 従来手法と提案手法の比較結果を図 $10,11,12$ に示す。提案手法においては，アシストトルクのピーク值を 抑え，その後の惰性を低いトルクで維持するような制御とな っており，その結果，従来手法と比較して加速が弱まり惰性 が伸びる走行となっていることが速度波形からもわかる。

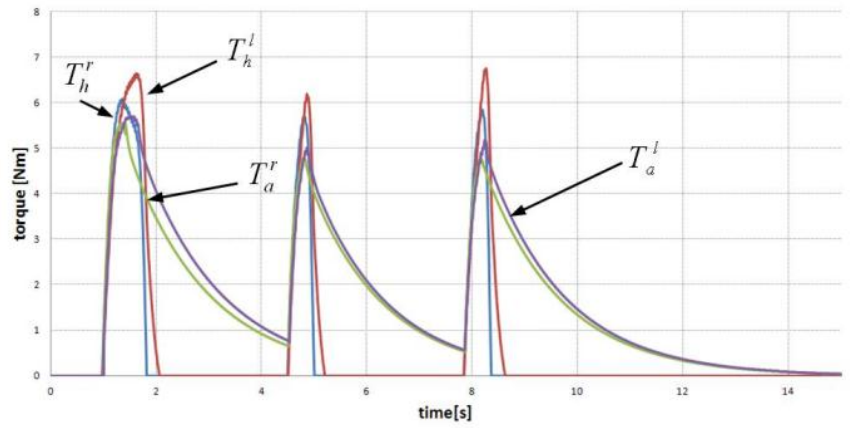

Fig. 10 Driving results with proposed control system (input torque and assisted torque)

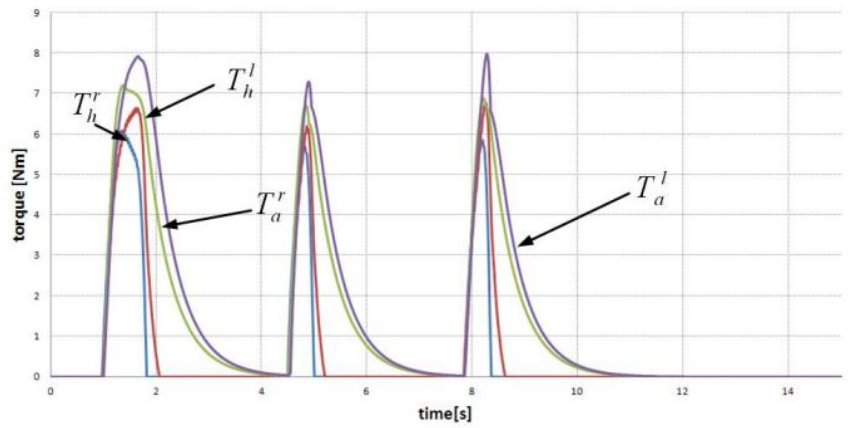

Fig. 11 Driving results without proposed control system (input torque and assisted torque) 


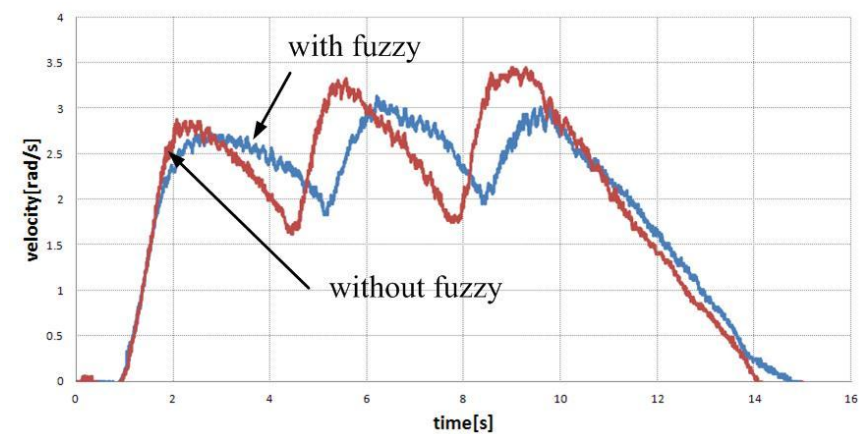

Fig. 12 Driving results (velocity)

一漕ぎと三漕ぎの各実験における走行効率の比較結果を図 13 に示す。いずれの実験でも提案手法の効率は向上しており, 特に三漕ぎという連続的な漕ぎ動作の際には効率が大きく向 上することがわかる。

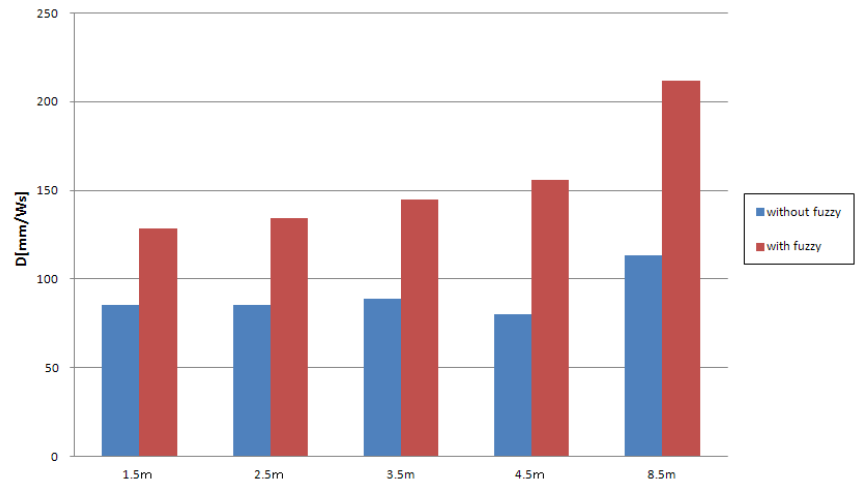

Fig. 13 Driving efficiency results

\section{2 長距離走行実験}

次に，従来手法と提案手法に加え，製品版のアシスト車い す（ヤマ八発動機（株）製 JW-II） も比較対象とし，約 $1[\mathrm{~km}]$ の長距離走行実験を行う。製品版には電流センサを両車輪に 取り付けデータロガーを用いて消費電力を測定する。これら 三者の制御法に対し，同様の力で漕ぎ直線平坦路面を往復す ることでいずれも約 $1[\mathrm{~km}]$ の走行を行い, 走行効率を比較する。

図 14 にその比較実験結果を示す。提案手法では約 $0.35[\mathrm{~m} / \mathrm{W} ・ \mathrm{~s}]$ となり, 基礎的検証実験の際よりも連続的に漕ぐ 動作が多く走行効率が向上した。他の手法と比較すると, 従 来手法よりも $93 \%$, 製品版よりも $40 \%$ の効率向上が確認でき, 提案手法の有効性が示された。

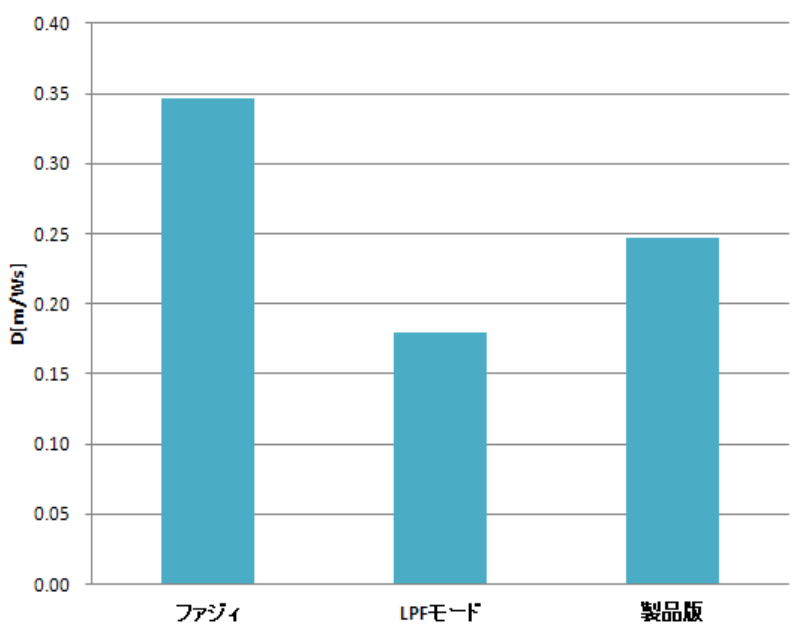

Fig. 14 Driving efficiency results

\section{6. 緒言}

本稿では電動アシスト車いすの低消費電力走行を実現する ためのファジィ推論形走行制御法を提案し，実機による検証 を行った。ファジィ推論により適切なアシストトルク生成を 行うことで，同一距離を走行するための消費電力を大きく抑 制することが可能となり，特に製品版との比較実験では $40 \%$ もの消費電力削減が可能であるという顕著かつ画期的な成果 が得られた。今後は不整地や傾斜路面などの外乱路面での走 行性能との両立などを検討していく。

\section{文 献}

[1] 内山敦，福井巧，"パワーアシスト車椅子の制御システム,", 目 本機械学会シンポジウム講演論文集, pp.204-208, 1997.

[2] H. Seki, K. Ishihara and S. Tadakuma, "Novel regenerative braking control of electric power assisted wheelchair for safety downhill road driving," IEEE Trans. on Industrial Electronics, vol.56-5, pp.1393-1400, 2009.

[3] H. Seki and N. Tanohata, "Fuzzy control for electric power-assisted wheelchair driving on disturbance roads," IEEE Trans. on Systems, Man, and Cybernetics-Part C, vol.42-6, pp.1624-1632, 2012. 